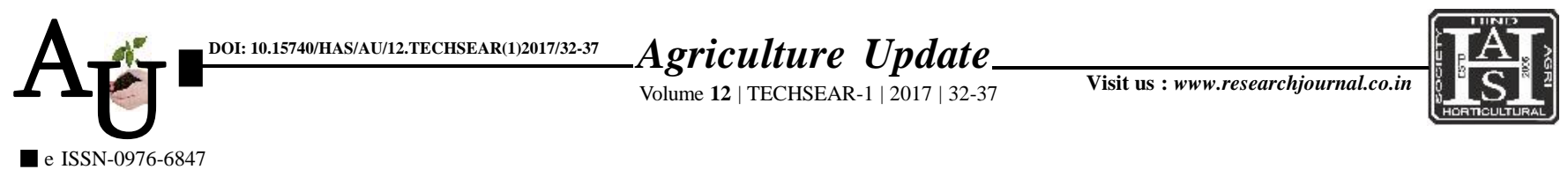

\title{
Rеsearch Aвticle: Effect of dates of sowing and topping on seed yield of white jute in new Alluvial zone of West Bengal
}

KASTURI GHOSH, BIKAS CHANDRA PATRA, KORLA ADITYA CHOWDARY AND MILAN KANTI KUNDU

Article Chronicle: Received :

05.07.2017;

Accepted :

22.07.2017

KeY Words:

Date of sowing, Gross return, Jute, Seed yield, Topping

Author for correspondence :

\section{KASTURI GHOSH}

Department of

Agronomy, Bidhan

Chandra Krishi

Viswavidyalaya,

Mohanpur, NADIA (W.B.)

INDIA

Email:kasturighosh1991@

gmail.com

See end of the article for

authors' affiliations
SUMMARY : A field experiment was carried out during the Kharif season of two consecutive years 2014 and 2015 at Instructional Farm, Jaguli, Bidhan Chandra Krishi Viswavidyalaya, Nadia, West Bengal with the focal objective to improve the jute seed yield in white (capsularis) jute by adoption of agrotechniques like dates of sowing and topping. The Capsularis variety JRC-698 was sown in three different dates $\left(1^{\text {st }}-15^{\text {th }}\right.$ June, $2^{\text {nd }}-15^{\text {th }}$ July and $3^{\text {rd }}-15^{\text {th }}$ August) with 4 topping (clipping of apical portion) operations performed at 30, 45 and 60 days after sowing (DAS) and no topping as control. Significant variations were observed on the performance of the crop under the different treatment combinations except in case of test weight. Results showed that among all the three dates of sowing, $15^{\text {th }}$ June sown crop recorded maximum seed yield of $295.02 \mathrm{~kg} \mathrm{ha}^{-1}$ and $333.67 \mathrm{~kg} \mathrm{ha}^{-1}$ leading to higher gross return (Rs. $73926.75 \mathrm{ha}^{-1}$ and Rs. $83457.25 \mathrm{ha}^{-1}$ ), higher net return (Rs. $46776.75 \mathrm{ha}^{-1}$ and Rs. $54957.25 \mathrm{ha}^{-1}$ ) and high B: C ratio of 2.72 and 2.93 in 2014 and 2015, respectively. Topping at 45 DAS exhibited superior performance with regard to all the yield parameters and gave higher seed yield $\left(319.63 \mathrm{~kg} \mathrm{ha}^{-1}\right.$ and 358.1 $\mathrm{kg} \mathrm{ha}^{-1}$ ) over other topping treatments which resulted in higher B: C ratio of 2.33 and 2.58 in 2014 and 2015, respectively. Among the treatment combinations, the best treatment observed was the first date of sowing ( $15^{\text {th }}$ June) and topping at 45 days $\left(30^{\text {th }}\right.$ July) which resulted in the highest seed yield of $353.76 \mathrm{~kg} \mathrm{ha}^{-1}$ and $394.10 \mathrm{~kg} \mathrm{ha}^{-1}$ leading to highest gross return of Rs. $84963.20 \mathrm{ha}^{-1}$ and Rs. $95587.00 \mathrm{ha}^{-}$ ${ }^{1}$, highest net return of Rs. 52963.20 ha $^{-1}$ and Rs. 62087.00 ha $^{-1}$ and best B:C ratio of 2.66 and 2.85, respectively in both the years.

How to cite this article : Ghosh, Kasturi, Patra, Bikas Chandra, Chowdary, Korla Aditya and Kundu, Milan Kanti (2017). Effect of dates of sowing and topping on seed yield of white jute in new Alluvial zone of West Bengal. Agric. Update, 12(TECHSEAR-1) : 32-37; DOI: 10.15740/HAS/AU/12.TECHSEAR(1)2017/32-37. 